\title{
19. 旧島津藩領内における棒踊りの社会体育的考察について
}

网崎女子知㺫大学○北 沢清

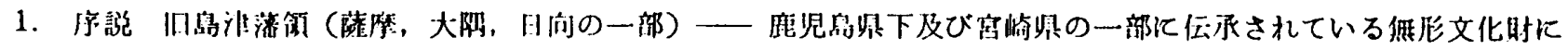

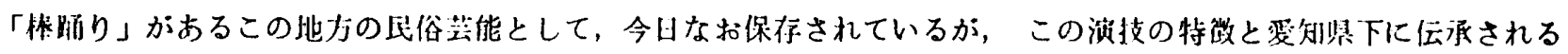

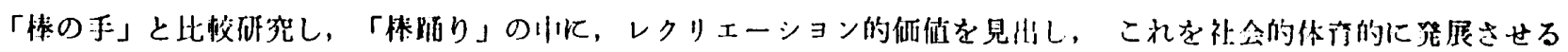
ため，その方法論を考察する。

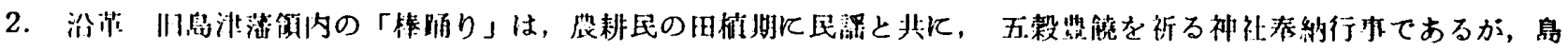

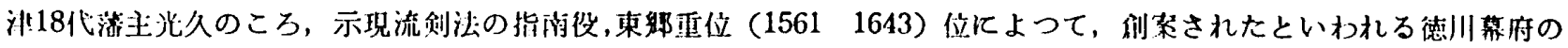

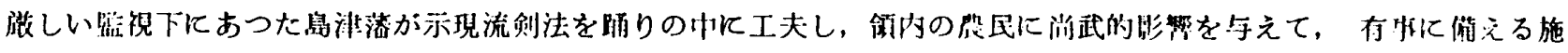
策の一つとみられる。

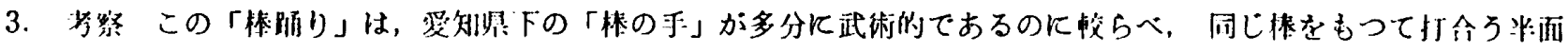

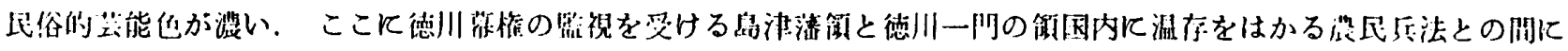

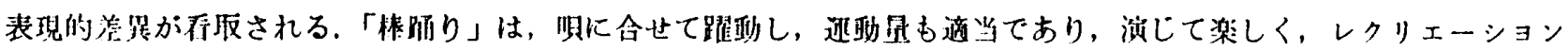

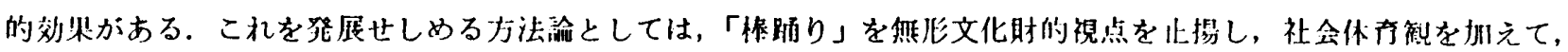

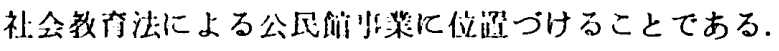

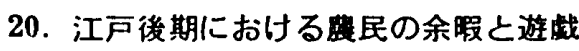

文化女子大学室薂短期大学 跲 木 敏 夫

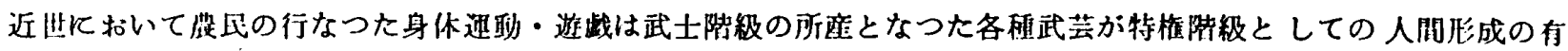

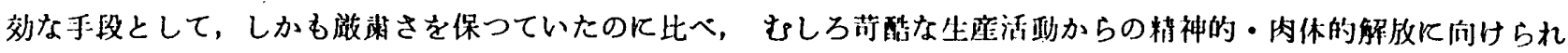
ていた所にその特貿がある。

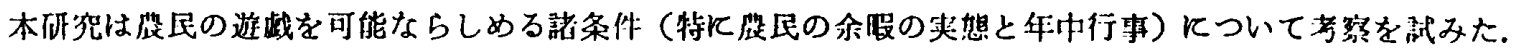

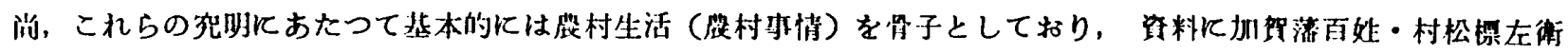
问「村松家訓」を用いて迫究した。

(數約)

○榄民の遊日は 1 月・6月・7月・8月と多い。（遊日は年間を通じて24日）

○ 年中行扑——年间総数28日であり，少くとも尉民は月平均 2 回程度の宗教行本とかかわりを保つ.

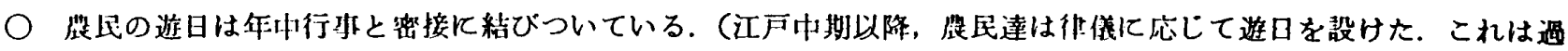

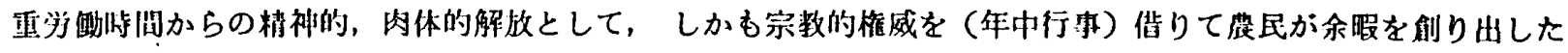
と胃てさしつかえない。

\section{1. 平戸藩における武芸教育（松流静山を中心として）}

長崎祡立女子短期大学 富 永 好 松

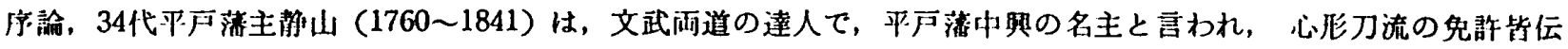

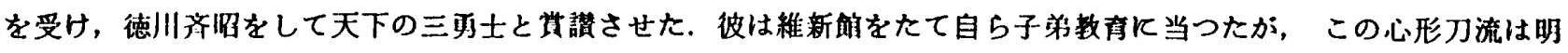
治 4 年化一藻の创法と定められた。

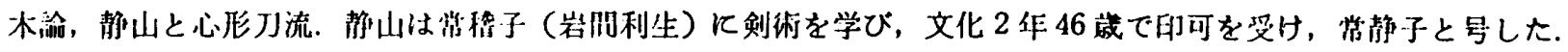

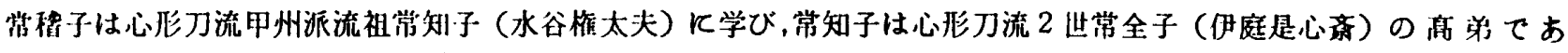

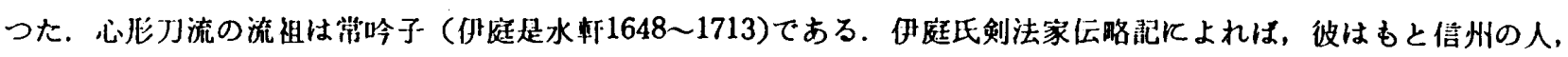

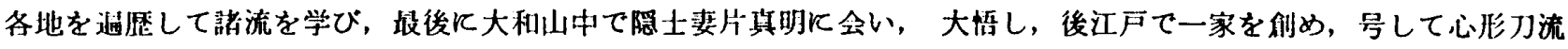

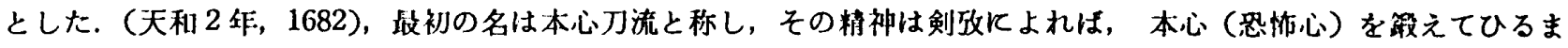

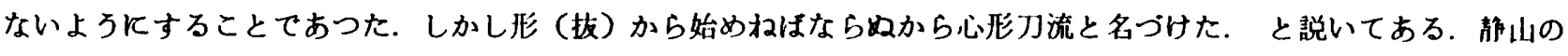

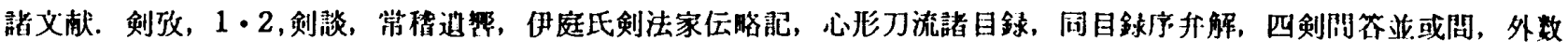

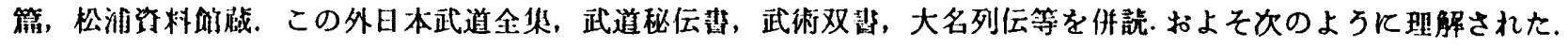

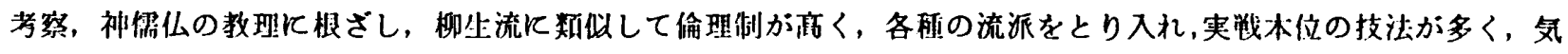
力帐箱である。 